UDC 338.1: 338.3

JEL: 031, 033, 011

\section{Artūras Jurgelevičius}

Doctor of Economics, Institute of Business and

Economics,

Faculty of Public Governance and Business,

Mykolas Romeris University, Vilnius, Lithuania

E-mail: bplanet7@gmail.com orcid.org/0000-0002-2217-6686

\section{Nadežda Kučaidze}

Doctor of Economics, Institute of Public Administration, Faculty of Public Governance and Business, Mykolas Romeris University, Vilnius, Lithuania

E-mail: n.kucaidze@mruni.eu orcid.org/0000-0001-5724-2463

Received: August, 2020

Accepted: October, 2020

DOI:10.31520/2616-7107/2020.4.4-1

(C) Economics. Ecology. Socium, 2020 CC BY-NC 4.0 license

\section{THE DEVELOPMENT OF INNOVATIVE STARTUPS AND TECH BASED COMPANIES IN EUROPEAN COUNTRIES}

Introduction. The global structure of economy and business has been changing. New technologies and innovations occurred replacing or minimizing the role of old once. A number of traditional companies and industries must adopt new emerging technologies in order to survive on the international market. Moving from industrial society to Industry 4.0 society a few critical transformations should be taken into account. If it is understandable that innovations and technologies can benefit the whole economy and society in many ways, it is important to analyze what are the external factors that accelerate the development of innovative startups and technologies to boost the growth, development and welfare of societies and economies.

Aim and tasks. The purpose of this article is to assess the development of startups and technology based companies in a number of European countries and to identify a group of countries that has the most favorable environment for startups and technology proliferations.

Results. The findings of the research revealed that the most favorable countries for startup and technology-based companies' creation are Scandinavian and Western European countries, the least ones - mainly Balkans. The findings claim that macroeconomic stability and skills (broaden concept is human capital) are the most important factors influencing the creation and adoption of startups and technology-based companies. Meanwhile the national market size is the least important factor.

Conclusions. The conducted research presents that the most favorable countries for innovative startups and tech-based companies are mainly Scandinavian and Western European countries. It is important to notice that Scandinavian countries have exceptionally leading the list in this field. As analysis showed, macroeconomic stability and skills (to a broader concept human capital) are the most significant factors for technologies and innovations to occur. Finally, the market size seems to be the least important factor for technology and innovative startup development. It can be explained that startups and technologies by its nature are scalable businesses those market is entire globe.

Keywords: startups, technology, innovations, European economies. 
УДК 338.1: 338.3

JEL: 031, 033, 011

\section{Артурас Юргелевічюс}

Доктор економічних наук, Інститут бізнесу та економіки, факультет державного управління та бізнесу, Університет Миколаса Ромеріса, Вільнюс, Литва

E-mail: bplanet7@gmail.com orcid.org/0000-0002-2217-6686

\section{Надія Кучайдзе}

Доктор економічних наук, Інститут державного управління, факультет державного управління та бізнесу,

Університет Миколаса Ромеріса, Вільнюс, Литва

E-mail: n.kucaidze@mruni.eu orcid.org/0000-0001-5724-2463

Отримано: Серпень, 2020

Прийнято: Жовтень, 2020

DOI:10.31520/2616-7107/2020.4.4-1

(C) Економіка. Екологія. Соціум, 2020 CC BY-NC 4.0 ліцензія

\section{РОЗРОБКА ІННОВАЦІЙНИХ СТАПАРТІВ І ТЕХНОЛОГІЧНИХ КОМПАНІЙ В ЄВРОПЕЙСЬКИХ KPAÏHAX}

Вступ. Глобальна структура економіки та бізнесу змінювалася. Нові технології та інновації відбулися, замінюючи або мінімізуючи роль існуючих. Ряд традиційних компаній та галузей повинні застосувати нові технології, щоб конкурувати на міжнародному ринку. Переходячи від індустріального суспільства до суспільства Індустрії 4.0, слід взяти до уваги кілька критичних перетворень. Якщо зрозуміло, що інновації та технології можуть багато в чому принести користь всій економіці та суспільству, важливо проаналізувати, які зовнішні фактори прискорюють розвиток інноваційних стартапів та технологій для стимулювання зростання, розвитку та добробуту суспільств та економік.

Мета і завдання. Мета цієї статті - оцінити розвиток стартапів та компаній, що базуються на технологіях, у ряді європейських країн та визначити групу країн, яка має найбільш сприятливе середовище для стартапів та розповсюдження технологій.

Результати. Результати дослідження показали, що найбільш сприятливими країнами для створення стартапів та технологічних компаній $\epsilon$ скандинавські та західноєвропейські країни, найменші - переважно Балкани. Отримані дані стверджують, що макроекономічна стабільність та навички (розширене поняття - це людський капітал) $є$ найважливішими факторами, що впливають на створення та впровадження стартапів та компаній, що базуються на технологіях. Тим часом розмір національного ринку є найменш важливим фактором.

Висновки. Проведене дослідження показує, що найбільш сприятливими країнами для інноваційних стартапів та компаній, що базуються на технологіях, $\epsilon$ переважно країни Скандинавії та Західної Свропи. Важливо відзначити, що скандинавські країни винятково очолюють список у цій галузі. Як показав аналіз, макроекономічна стабільність та навички (до більш широкої концепції людський капітал) $\epsilon$ найважливішими факторами для розвитку технологій та інновацій. Нарешті, розмір ринку видається найменш важливим фактором для розвитку технологій та інноваційних стартапів. Можна пояснити, що стартапи та технології за своєю природою $є$ масштабованим бізнесом, цей ринок - цілий світ.

Ключові слова: стартапи, технології, інновації, європейська економіка. 
Introduction. The global structure of economy and business has been changing. New technologies and innovations occurred replacing or minimizing the role of old once. A number of traditional companies and industries must adopt new emerging technologies in order to survive on the international market. Moving from industrial society to Industry 4.0 society a few critical transformations should be taken into account.

Firstly, it is observed that the output of production and profit margins has been slow down giving less opportunities for investors to allocate the capital.

Secondly, the life cycle of products has shrunk several times and extremely high level of competition has emerged worldwide.

Thirdly, life style, habits, behavior of consumers has changed and is changing every year very fast.

All these phenomena creates assumptions to appear for new business and management methods, for instance, LEAN methodology in creating innovations and other technologies. Business environment became very different from those when the first management theories were created in XVIII XIX centuries. It is observed a new trend in entrepreneurship studies to explore a new phenomenon as startups that are mainly technologically based innovations.

If it is understandable that innovations and technologies can benefit the whole economy and society in many ways, it is important to analyze what are the external factors that accelerate the development of innovative startups and technologies to boost the growth, development and welfare of societies and economies.

Literature review. The concept of innovative startups and technology based companies analyzed by different scholars [1], [2], [3], [4]. Weiblen \& Chesbrough [2] claimed that startups have different features than matured companies. Ries [1] described startups as humans' organizations that operate under extreme level of uncertainty. Ries [5] and Blank [6] introduced LEAN startup concept that describes the startups as repeatable and scalable businesses using the least possible resources and delivering optimal possible value. Arundel [7] described startups as companies that were created in order to use new technologies. Chung [8] claimed that one of the main feature of startups is ability to scale. Other scholars promote idea that startups must be technologically based products that has ability to scale fast [9], [10], [11]. Also important attitude on innovative startups claim that startups have limited resources and access to the finance because of their nature of uncertainty [12], [13], [14].

Salamzadeh \& Kirby [15] the evolution of startups and technology-based companies divided into three levels macro, messo and micro. As scholars stated that factors at macro level play a vital role in determination of startups and technology creations. The scope of this article has a focus on the macro parameters of the environment of innovative startups.

The purpose of this article is to assess the development of startups and technology based companies in a number of European countries and to identify a group of countries that has the most favorable environment for startups and technology proliferations.

The presentation of the main research material. As an importance of startups and technology-based companies is rapidly growing, the deeper analysis is required to understand what are the external factors influencing the process. In order to estimate and identify the most favorable countries for startup and technology creation, several methods were applied in the research. First of all, in order to select the right indicators, literature review was conducted. The main indicators were chosen from World Economy Forum reports. These indicators represented in the Table 1. 
Table 1. The startups and tech based companies represented indicators

\begin{tabular}{lc}
\hline Risk capital accessibility & $K E 1$ \\
\hline FDI and technology transfer & $K E 2$ \\
\hline The newest technology accessibility & $K E 3$ \\
\hline The tech savvines of companies & $K E 4$ \\
\hline The sophistication of production & $K E 5$ \\
\hline Busisiness expenditure on R\&D & $K E 6$ \\
\hline University and business cooperation & $K E 7$ \\
\hline Patents & $K E 8$ \\
\hline The potential of innovations & $K E 9$ \\
\hline
\end{tabular}

Source: authors 'creation

Thus, after performing a principal component analysis and distinguishing the indicators reflecting the most analyzed phenomenon and selecting the coefficients, an analytical equation can be formed (1).

$$
Y(S T I)=0,355 *(K E 3)+0,359 *(K E 4)+0,358 *(K E 5)+0,357 *(K E 6)+0,352 *(K E 9)
$$

Where:

Y - Startups and tech-based companies 'index (STI)

KE3 - The newest technology accessibility

KE4 - The sevviness of technology based companies

KE5 - The sophistication level of production

KE7 - University and business cooperation

KE9 - The potential of innovations

In this particular case, it can be seen that the values of the coefficients of the selected indicators are very similar. It can reasonably be said that the analyzed indicators have a very similar importance in the calculation of the index. Although the selected indicators are different, they are interconnected and do not contradict each other.

Finally, the level of startups and technology-based companies were estimated and presented in the Fig. 1. These countries can be categorized in 5 relative groups. In the first group, countries mainly from the Balkan countries were entered (Bosnia \& Herzegovina, Serbia, Albania, Macedonia and Bulgaria). It's important to note that these countries have relatively higher agricultural and low value added sectors in the GDP. Second group is formed by Greece, Romania, Montenegro, Russian Federation and Latvia. That is to say, mostly Eastern and South European countries.
The third group is included with Croatia, Poland, Hungary, Italy and Lithuania. In fourth group following countries appeared as Slovak Republic, Malta, Spain, Slovenia, Estonia, Cyprus, Portugal and Czech Republic. This group is more involved with Central and South European countries. Finally, the fifth group is represented exceptionally by Western European and Scandinavian countries (Ireland, Luxembourg, United Kingdom, Belgium France, Netherlands, Iceland, Austria, Norway, Denmark, Germany, Finland, Switzerland and Sweden). It is important to pay attention that Scandinavian countries are nearly the leaders in this group, basically leading the whole list.

As this graph shows the most startup and tech savvy top 5 countries is ranked Sweden, Switzerland, Finland, Germany and Denmark. This is the reason why these samples should be analyzed in more detail way. 


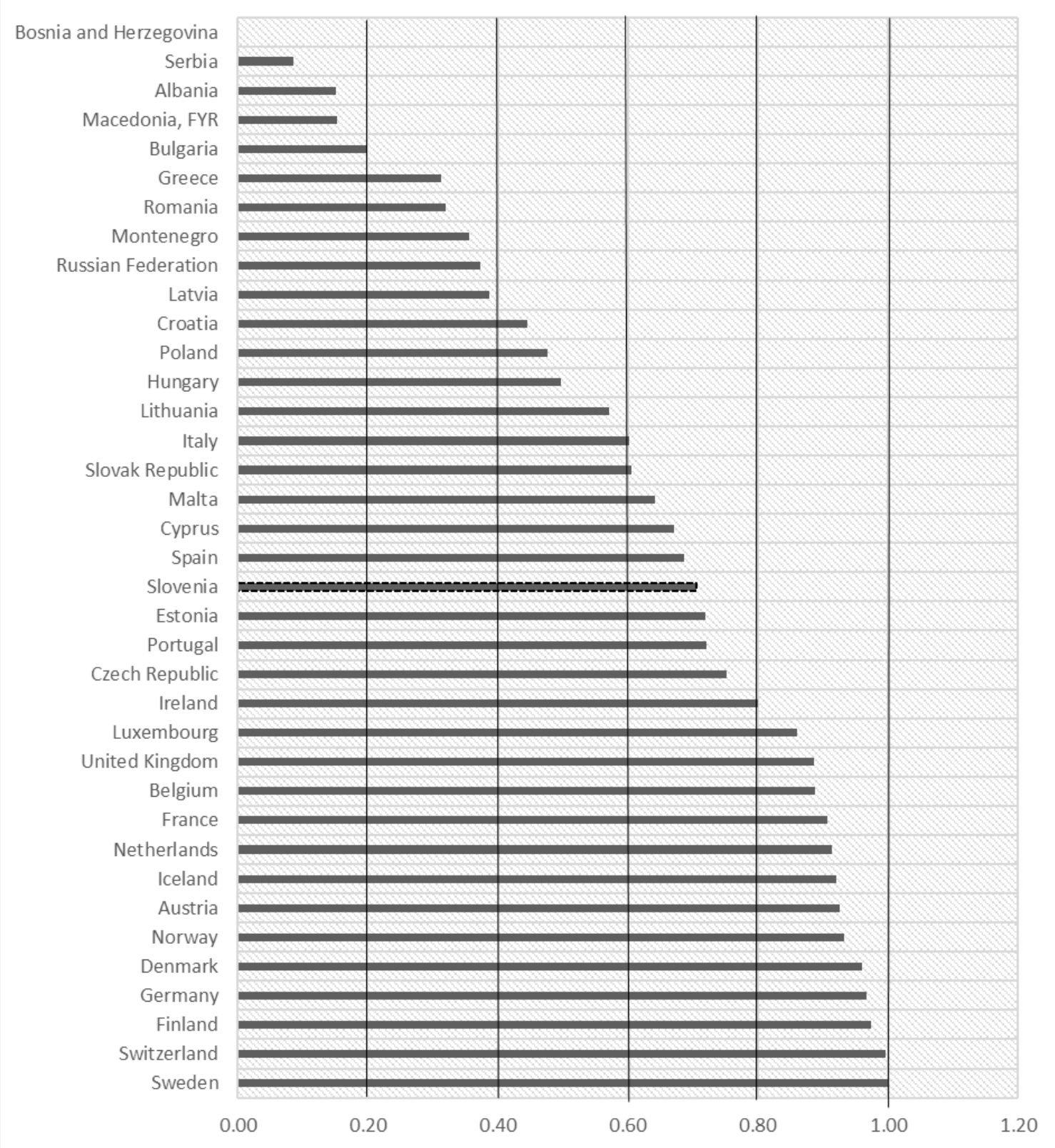

Fig 1. The level of startups and tech-based companies in European countries Source: authors 'creation

Based on the research top 5 countries where selected that scored the highest level in the conducted research. These countries were selected from World Economic Forum reports of 2019 and systemized their scores by 12 factors (institutions, infrastructure, ICT adoption, macroeconomic stability, health, skills, product market, labor marker, financial system, market size, business dynamism, innovation capability) [17].

Two major factors unite all top 5 countries: macroeconomic stability and skills.
By the macroeconomic stability, countries are exceptionally ranked as the most stable countries and by the skills; countries are grouped as top 10 countries in the world.

Macroeconomic stability namely is measured by price stability (inflation) and debt dynamics. It means that for startups and technology-based companies' stable environment is one of the key factors. On one hand, innovative startups and new technologies by its definitions operate in extreme level of uncertainty [1]. 
Innovative startups and technology-based companies do not know who is their real customers, what business model is the right for a certain market, which channels to use to attract first clients, what pricing should be used and always there is a high level of risk of competitors' entrance. Because of these factors, innovative startups are enforced to act under extreme level of uncertainty. That is to say, that stable macroeconomic environment accelerates innovative startups creation and mitigate other factors of risks. Under stable macroeconomic environment, potential consumers are willing to try new products. In other words, the number of early adopters can be higher. Even under conditions of extreme uncertainty, innovative startups can perform planning and business model validation as well as dealing with suppliers.

Another key factor that unites all top 5 countries is skills. The following indicators measure skills: mean years of schooling, extent of staff training, quality of vocational training, skillset of graduates, digital skills among active population, easy of finding skilled employees, school life expectancy, critical thinking in teaching, pupil-to-teacher ratio in primary education. It is obvious that high technologies and innovations require high tech skills including programming or digital skills. On one hand, quantitative indicators are included in the assessment, on another hand, qualitative such as critical thinking in teaching. It is important to notice, that skills or broader concept as human capital is a factor of production and at the same time is the factor as consumers in the market. Ability to produce innovative products based on technologies is more controlled factor. However, to spread and adopt such innovative products requires high and critical level of the skills in society itself that would be able to use and consume such products at massive scale. The number of early adopters of innovation products is a critical factor for venture capital funds and angel investors to take decision to invest in early stage startups or technology development. It can be stressed that the higher level of digital skills the society is possessed, the higher probability to spread and adopt tech-based products in the market. Moreover, it is important to mention that analyzed countries have very high level of open and tolerance society. As Tvaronaviciene and Jurgelevcius [18] provided with evidence that human capital's values, beliefs, attitudes and social norms create preconditions for individuals come into intensive interaction in the society, which results in knowledge sharing, creativity and new ideas formation. Trust, tolerance, openness and cultural diversity are critical factors for innovative startups and technologybased companies to occur and grow. These are the major factors, which distinguish Scandinavian countries from others.

Additionally, market size, as GDP in PPP and imports of goods and services \% of GDP, is the least important factor for innovative startup and technology creation observed in the comparison of indicators. In this case, market size is not an essential factor for launching an innovative startup because the effect of economy of scale lose it sense. Building a scalable innovative startup leads to the fact that the market size of product realization is the entire world and economy of scale is achieved. It can be admitted that market size is not a major factor for innovative startup and technology development.

Conclusions. The conducted research presents that the most favorable countries for innovative startups and tech-based companies are mainly Scandinavian and Western European countries. It is important to notice that Scandinavian countries have exceptionally leading the list in this field. As deeper analysis showed, macroeconomic stability and skills (to a broader concept human capital) are the most significant factors for technologies and innovations to occur. Finally, the market size seems to be the least important factor for technology and innovative startup development. It can be explained that startups and technologies by its nature are scalable businesses those market is entire globe.

It is important to develop an extended framework of key factors influencing innovative startups and technology creation and adaptation in the market. This can be done in the future research conducted by the authors. 


\section{REFERENCES}

1. Ries, E. (2017). The startup way: how modern companies use entrepreneurial management to transform culture and drive long-term growth. Crown Publishing Group.

2. Weiblen, T., Chesbrough, H. (2015). Engaging with startups to enhance corporate innovation. California Management Review, 57(2), 66-90.

3. Blank, S., Dorf, B. (2012). The startup owner's manual: the step by step guide for building a great company. Pescadero.

4. Jonikas, D. (2017). Startup evolution curve. From idea to profitable and scalable business: startup marketing manual. Publisher: Createspace Independent Publishing Platform.

5. Ries, E. (2011). The lean startup: how today's entrepreneurs use continuous innovation to create radically successful businesses. New York: Crown Business.

6. Blank, S. (2013). Why the lean start-up changes everything. Harvard Business Review, 91(5), 63-72.

7. Arundel, A., Barjak, F., Es-Sadki, N., Husing, T., Lilischkis, S., Perrett, P., Samuel, O. (2012). Respondent report of the knowledge transfer study.

8. Chung, H., Chen, C., Hsieh, T. (2007). First geographic expansion of startup firms: initial size and entry timing effects. Original research article journal of business research, 60 (4), 388-395.

9. Trott, P. (2008). Innovation management and new product development. $4^{\text {th }}$ edition, Pearson education lim.

10. Nanda, R. Rhodes - Kropf, M. (2013). Investment cycles and startup innovation. Journal of Financial Economics, 110 (2), 403 - 418.

11. Mahajan, V., Muller, E., Wind, Y. (2000). EW- product diffusion models. Spring science \& business media.

12. Alvarez, S., Busenitz, L. (2001). The entrepreneurship of resources based theory. Journal of Management, 27, 755-775.

13. Pfeffer, J., Salancik, G.R. (2003). The external control of organizations: a resources dependence perspective. Stanford University Press.

14. Simpeh, N.K. (2011). Entrepreneurship theories and empirical research: a summary review of the literature. European Journal of Business and Management, 3(6), $1-8$.

15. Salamzadeh, A., Kirby, D. A. (2017). New venture creation: how start-ups grow? ADminister No. 30 January- June, pp. 9-29.

16. OECD (2008). Handbook on constructing composite indicators: methodology and user guide.

17. World Economic Forum. (2019). The global competitiveness report. Switzerland.

18. Tvaronaviciene, M., Jurgelevicius, A. (2020). The new concept of human capital and its impact on economy in European countries. Polish Journal of Management Studies (in press). 